'ON MY GROUND':

INDIGENOUS FARMERS

AT NEW NORCIA

1860s-1900s

\title{
Tiffany Shellam
}

School of Humanities and Social Sciences

Deakin University 


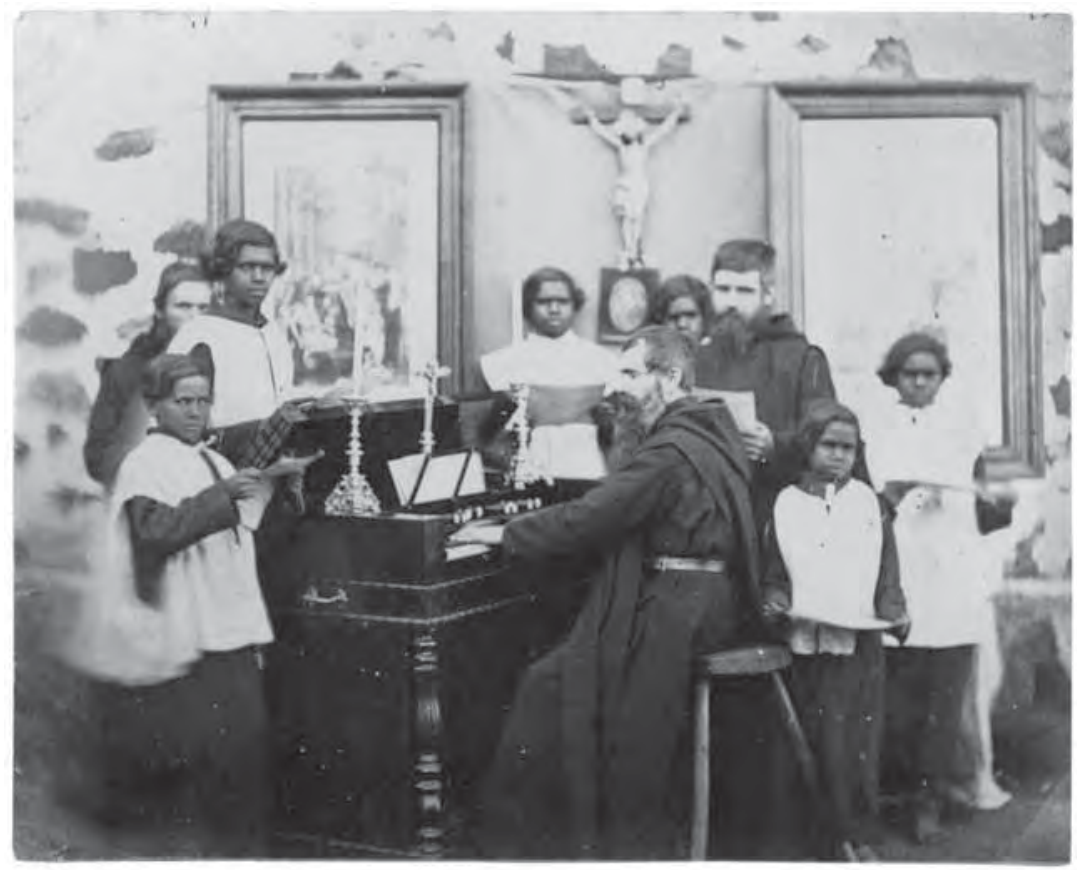


[T] hey have their own standard of right and wrong, which no argument of the white man can change. Good actions and morals they acknowledge and praise as "Kuoba" - right; but whatever is bad, they evidently regard and express as "Winda" - wicked. If occasionally the wildest Aborigines find a difficulty in defining the difference between killing a sheep and a kangaroo, - both of which are equally fed by grass and roam at large in their bush - it should, before condemning them, be first taken into consideration who shows the greatest dulness [sic] of moral perception, the unauthorized occupiers of their woods who kill, themselves, as many kangaroos as they can, or the original owners of that land, who take such things as they find upon it for the preservation of life ${ }^{1}$.

These words were penned in 1867 by Father Venancio Garrido, a Benedictine monk at New Norcia Aboriginal mission in Western Australia. They form part of his lengthy report on the mission which was requested by the Colonial Secretary to be forwarded to the Aborigines' Protection Society in London. In 1871 Father Garrido's report was collated alongside other 'information' about Aborigines in Western Australia that had been collected by missionaries and government agents, and was printed by the government printer. The above statement suggests two issues that I will draw out in this chapter: the Aboriginal residents at New Norcia had a strong sense of right and wrong; and the Benedictine community at New Norcia considered them to be the original owners of the land, which was, in 1867, increasingly occupied by pastoralists.

Between the 1860s and the early 1900s Aboriginal residents at New Norcia acted on and expressed their understandings of 'right' and 'wrong' in relation to land through group protests, letters and petitions to colonial authorities and the

\footnotetext{
${ }^{1}$ V. Garrido (1871), 'Letter from Rev V. Garrido to Colonial Secretary, Western Australia, 21 December 1867', in Information Respecting the Habits and Customs of the Aboriginal Inhabitants of Western Australia, compiled from various sources, Perth, government printer, ordered by the Council to be printed, 16 January 1871, Council, Western Australia, 1870-1871 and 1872, A.8 (State Records Office of Western Australia), p. 15.
} 
mission community. These Aboriginal statements, I argue, developed and had taken shape during the Aborigines' residence at New Norcia, where, in collaboration with the missionaries, the Aboriginal community developed a mode of political expression. Elizabeth Elbourne has written about some Indigenous men who, in the 1830 s, attempted to participate in international networks concerned with the reform of British colonial policy, using 'international languages about rights and property ownership'. She writes: 'They needed to present themselves in print or in person on the British stage as, to some extent, disembodied actors with the concomitant ability to move between different cultural worlds. They also often needed to be Christian, or at least to present themselves as such. They had to present themselves [...] in ways familiar to the British, while posing as examples of the universal man posited by early nineteenth-century liberalism'3. Benedict Cuper, Charles Ponan, Luke Mourdey and Paul Piramino were Aboriginal farmers at New Norcia who wrote letters of protest to authorities about their land. These men understood, to an extent, the political setting in which they were engaging, developing a political network and articulating their rights as they understood them and in a language that would sometimes bring justice. This activism can be discussed alongside the story of Coranderrk Aboriginal Station in Victoria. Set up in 1863 by the government to confine Victoria's remnant Aboriginal population, Aboriginal settlers at Coranderrk made the country their own, successfully settling and farming the land. However, the government re-dispossessed these people, taking them off their country in the 1870s. The Coranderrk residents' political mobility in response to government actions was described as a 'rebellion' by Diane Barwick, and more recent scholarship has located Aboriginal actions as operating within Aboriginal ideas of 'right' behaviour ${ }^{4}$.

\footnotetext{
${ }^{2}$ E. Elbourne (2005): 'Indigenous peoples and imperial networks in the early nineteenth century: The politics of knowledge', in Phillip Buckner and R. Douglas Francis (eds.), Rediscovering the British World, Calgary: University of Calgary Press, p. 63.

${ }^{3}$ E. Elbourne, 'Indigenous peoples and imperial networks', p. 61, quoted in Tim Rowse (2012), 'The identity of Indigenous political thought', in T. Rowse and L. Ford (eds.), Between Indigenous and Settler Governance, Hoboken: Taylor and Francis, p. 96.

${ }^{4}$ D. E. Barwick (1998): Rebellion at Coranderrk, Laura E. Barwick and Richard E. Barwick (eds.), Canberra, Aboriginal History Monograph, 1998; R. Broome (2006), “There were vegetables every year Mr Green was here": Right behaviour and the struggle for autonomy at Coranderrk Aboriginal Reserve', History Australia, vol. 3, no. 2.
} 
Besides the seminal work of Anna Haebich on Aboriginal farmers in 1984, the narrative of New Norcia's founder, Rosendo Salvado, and his enlightened approach to 'civilising' Aboriginal people has overshadowed the story of the political agitations of some of the mission residents in the early $1900 s^{5}$. This chapter reflects on the ways in which, determined to retain access to their land, Aboriginal farmers at New Norcia cultivated a space through their written protests to colonial authorities, in which they negotiated their changing identities of being both 'Aboriginal' and settled 'farmer'. Through their experiences of collaborating with the missionaries on petitions at New Norcia, and writing letters, this chapter aims to shed light on how some of the Aboriginal residents understood writing as a vehicle for action ${ }^{6}$.

\section{NEW NORCIA: LAND, LABOUR AND CIVILISATION}

Two Spanish Benedictine missionaries, Rosendo Salvado and Joseph Serra, arrived in the Swan River Colony in January 1846. They had been informed by Bishop Brady that large numbers of Aboriginal people lived in the Victoria Plains district, $100 \mathrm{~km}$ north of the Perth township. Salvado and Serra trekked to the banks of the Moore River and began setting up a mission on the ancestral country of the Yuit people.

Humanitarians in the mid-nineteenth century frequently linked Aboriginal futures with the adoption of agriculture. As Jessie Mitchell has written, in Europe in the eighteenth and nineteenth centuries, 'the cultivation of the soil and the private enclosure of land were primary factors legitimising ownership and denoting civilization'7. Rosendo Salvado had a vision of a self-supporting

\footnotetext{
5 A. Haebich (1988): For Their Own Good: Aborigines and Government in the South West of Western Australia, 1900-1940, Western Australia: University of Western Australia Press.

${ }^{6}$ For other examples of indigenous people utilising literacy and colonial modes of expression to voice their rights and concerns, see A. Curthoys and J. Mitchell (2011): "Bring this paper to the good Governor": Aboriginal petitions in Australian Colonies', in S. Belmessous (ed), Native Claims: Indigenous Law Against Empire, 1500-1920, Oxford: Oxford University Press, pp. 182-204; T. Banivanua Mar (2013): 'Imperial literacy and indigenous rights: tracing transoceanic circuits of a modern discourse', Aboriginal History, vol. 37; R. de Costa (2006): A Higher Authority: Indigenous Transnationalism and Australia, Sydney: UNSW Press.

7 J. Mitchell (2011): In Good Faith: Governing Indigenous Australia Through God, Charity and Empire, 1825-55, ANU E Press, p. 96.
} 
mission village after the model of European monastic towns where Benedictine monks would live alongside local Aboriginal families. Salvado and other missionaries who joined him at New Norcia hoped that the 'Australians', as he often called the indigenous population, would experience community stability as they would remain on their land. The 'Australians' would settle down as landholders and this would, Salvado hoped, assist them in the transition to 'civilised' life. Salvado realised that land was also crucial for the mission's success and survival - the government had granted Salvado 20 acres in 1847 - and Aborigines who came to New Norcia provided the labour required to further develop the mission. As Salvado wrote in 1857, 'with the help of 31 natives' the community 'reaped 20 acres in a day and a half".

Henry Reynolds has argued that hard labour was believed to prepare Aborigines for Christian conversion by teaching discipline, punctuality, sedentary life and the acceptance of European authority ${ }^{9}$. Humanitarians' advocacy for Aboriginal land retention was not neutral; indigenous 'compensation' for dispossession was tied to Christian agricultural instruction, and was often funded through the proceeds of dispossession itself. The Imperial Waste Land Act of 1842 , for example, required up to $15 \%$ of revenue to be allocated from the sale of 'waste' lands - Aboriginal country - to be spent on Aboriginal welfare ${ }^{10}$.

Salvado's focus on Aboriginal family units and his encouragement of men becoming farmers was central to his civilising plan. At Coranderrk, in Victoria, the station manager, John Green, also tied married life with Aboriginal stability, recruiting Aboriginal men with the promise of finding a wife ${ }^{11}$. The importance

8 'Letter from Salvado (New Norcia) to Garrido (Caltura), 27 December 1858', NNA Correspondence 2-2234A/13.125, translated from the Spanish by Teresa de Castro.

${ }^{9}$ H. Reynolds (1990): With the White People, Melbourne: Penguin, p. 90.

${ }^{10}$ For a discussion on this issue in the Swan River Colony, and the agitation for acknowledgement of Aboriginal land proprietary rights in the 1830s-40s, see A. Hunter (2012): A Different Kind of 'Subject': Colonial Law in Aboriginal-European Relations in Nineteenth Century Western Australia, 1829-61, North Melbourne, VIC: Australian Scholarly Publishing, especially chapter 8.

${ }^{11} \mathrm{~J}$. Green to Commissioners, 21 May 1877, Royal Commission on the Aborigines of Victoria: Report of the Commissioners, government printer, Melbourne, 1877, p. 83. See J. Cruickshank's work for examples on how humanitarian concerns about marriage were central to debates about civilisation in the early-mid- $19^{\text {th }}$ century, J. Cruickshank (2008): “To exercise a beneficial influence over a man”: Marriage, Gender and the Native Institutions in Early Colonial Australia', in Evangelists of Empire?: Missionaries in Colonial 
placed on family units is evidenced in a range of archival documents at New Norcia: census lists grouped families together, naming married couples and their children; Salvado stressed in his Memoirs (1851) that the family unit should become the locus of the property holding and the acquisitive behaviour he was keen to encourage ${ }^{12}$.

Land rewards were also given to Aboriginal couples who got married. The first Catholic marriage of Aborigines at New Norcia was on 24 February $1862^{13}$. The mission provided a two-roomed furnished brick cottage to married couples, a larder of provisions and steady employment ${ }^{14}$. Salvado believed labour and land improvement were the pathways to civilisation. Therefore, Salvado was sympathetic to Aboriginal land ownership and sensitive to his settlement on Aboriginal country. When, in 1864, he requested that he be the sole trustee of the land that New Norcia occupied (previously being trusted to Salvado and four local settlers) Salvado included in his letter to the Colonial Secretary that he had received 'the assent of the Aboriginal natives [who were] interested' in this matter ${ }^{15}$. This humanitarian desire to settle the Yuit on their own ancestral country was not intended as a way of preserving pre-colonial Aboriginal culture, but radically re-shaping it. Protected agricultural labour was offered as a form of redemption. However, as Mitchell argues: 'missionary efforts to change Aborigines into farmers of their ancestral lands' can also be seen as 'attempts to incorporate Aborigines into this colonising project in a rather more collaborative

History, Amanda Barry, Joanna Cruickshank, Andrew Brown-May and Patricia Grimshaw (eds.) [online], Melbourne: University of Melbourne eScholarship Research Centre. Available at http://msp.esrc.unimelb. edu.au/shs/missions, date accessed: $3^{\text {rd }}$ December 2013.

12 E. J. Stormon (1977): The Salvado Memoirs: Historical Memoirs of Australia and Particularly of the Benedictine Mission of New Norcia and of the Habits and Customs of the Australian Natives by Rosendo Salvado, 1851, translated and edited by E. J. Stormon, Western Australia: University of Western Australia Press.

13 'Letter from Garrido (New Norcia) to Salvado (Perth), 24 February 1862', Correspondence in Spanish, 2-2234A/17.053, NNA, translated by Teresa de Castro.

${ }^{14}$ Letter from R. Sala: 'Five weddings were celebrated a short while ago for recently-converted Aborigines. A new well-furnished cottage was given to each couple', in El Misionero Romualdo: Un vivo recuerdo que a los hermanos, parientes, amigos y conocidos les dedica un amante de su familia, Palma de Mallorca, translated and cited by David Barry (2005): 'A Mallorcan in New Norcia: Missionary Brother Romualdo Sala', New Norcia Studies, September, no. 13.

15 'R. Salvado to Colonial Secretary, 10 August 1864', NNA, 174 2-2234A/19.174. The subsequent legal document is located in NNA, 202, 2-2234A/19.202. 
way. Aborigines would, missionaries hoped, be integrated into the colonial economy while kept safely isolated from European dependence and $\sin ^{16}$. Father Garrido, reflecting on the civilising policy at New Norcia in his 1867 report, wrote how 'it is essentially of greater advantage to any Aboriginal native who learns how to support himself by his industry or manual labour, as an agriculturalist, teamster, shepherd, shearer, or trademan [...] than only to know how to read, write, cipher...'17 Mitchell has argued that 'missionaries and protectors frequently described their mission's progress in terms of 'simultaneous religious enlightenment and 'industry and general steadiness' ${ }^{18}$. This idea of progress and steadiness was part of the language that Aboriginal farmers and settler supporters adopted or engaged with when writing to the authorities about retaining their land.

As soon as a site for the mission was chosen, Salvado began to lobby to expand the original government grant of 20 acres, and by the end of 1848 the mission had over 1000 acres, and over 1000 sheep. Crops and vegetables were also grown. Initially Salvado assigned a piece of land and cattle each to four Yuit men: Bilagoro, Dwergan, N-yalbinga and Takencut in April 1848. By the end of 1857, these men were living in the four cottages that had been built specifically for them and their families. These gifts of cottages, land and cattle were aligned with Salvado's goal of ensuring Aboriginal private ownership. Dwergan's cow, for example, was branded with a D to denote his possession of it - a graphic index of property held individually rather than communally ${ }^{19}$. As Father Garrido stated in 1867, 'The possession of private property is, no doubt, an encouragement to industry, and a salutary check upon the natural indolence of the Australian Aborigines' ${ }^{20}$. Progress, no matter how slow, was always celebrated by the missionaries. In 1856 Fr Martelli reported to Salvado

16 J. Mitchell (2004): "Country Belonging to Me": Land and Labour on Aboriginal Missions and Protectorate Stations, 1830-1850', ERAS Journal, edition 6, November [online]. Available at http:// artsonline.monash.edu.au/eras/, date accessed: $5^{\text {th }}$ December 2013.

${ }_{17}$ V. Garrido to Colonial Secretary, Information Respecting the Habits and Customs of the Aboriginal Inhabitants, p. 16.

18 J. Mitchell: "“Country Belonging to Me", p. 5.

19 'Letter from R. Salvado to S. Salvado, 12 May 1856', Correspondence, NNA ACC 202234A/11.062.

${ }^{20} \mathrm{~V}$. Garrido to Colonial Secretary, Information Respecting the Habits and Customs of the Aboriginal Inhabitants, p. 16. 
that 'It was heartening to see land being cultivated for the natives, but it would be better still if the natives themselves could be doing the work' ${ }^{21}$. Two years later Salvado wrote: 'The Australians are clearing ground to work for themselves. They made their own choice of land and chose well. They work together in groups of two or three, which cooperate when need arises'22. Salvado found this work 'very encouraging' and had 'high hopes for the success of the enterprise'23.

New Norcia, and Salvado as superintendent, quickly became a model of success in Western Australia and other colonies, where it received positive press. Sydney's Archbishop Polding wrote to Salvado in August 1863 congratulating him on the 'unequalled success in civilising the natives' 24 . There was much weighing on Salvado's success in 'settling' the Australians. In a letter from Corrons in Palermo in 1862 to Salvado, Corrons stressed that 'the [Benedictine] Order is in decline, and the Australian savage may be the plank on which the shipwrecked Order reaches safety ${ }^{25}$.

Learning new farming techniques was not limited to Aborigines. As Mary Eagle has written, the Aborigines at New Norcia 'taught skills of firestick farming, water management, reading the weather, rain-making, living off the land, rug-making, music and dance' to the Brothers ${ }^{26}$.

Salvado paid the Aboriginal residents who farmed and also helped the men establish their own farms. The wages they earned enabled them to take up a section of land to work and crop for their own benefit. Salvado set up a banking scheme, encouraging the men to buy animals or equipment ${ }^{27}$. As Salvado described his scheme:

\footnotetext{
21 'Letter from Martelli (Toodyay Village) to R. Salvado (Fremantle), 23 June 1856', Correspondence, NNA ACC 2-2234A/11.081.

22 'Letter from R. Salvado to V. Garrido, 25 June 1858', Correspondence, NNA ACC MF12 41.07.

23 'Letter from R. Salvado to V. Garrido, 25 June 1858', Correspondence, NNA ACC MF12 41.07.

24 'Letter from Archbishop Polding (Sydney) to Salvado (New Norcia), 21 August 1863', Correspondence, NNA 2-2234A/18.108.

25 'Letter from Corrons to R. Salvado, 27 January 1862', Correspondence, NNA 2-2234A/17.021.

${ }^{26}$ M. Eagle (2002): 'Monop of New Norcia and the Victoria Plains', New Norcia Studies, 10, p. 50. Eagle has written that Aborigines who specialised in detecting water were sent to make wells for the mission. 27 'Letter from V. Garrido to Colonial Secretary', Information Respecting the Habits and Customs of the Aboriginal Inhabitants, p. 12.
} 
to have Aboriginal men working without recompense or reward would make them feel the burden of civilisation without its advantages [...] should there be no recompense, the natives prefer the freedom of bush life, and they return to the bush. Properly instructed the aboriginal acquires a just idea of both the value of money and property, and diligently studies thenceforth how we may better his condition ${ }^{28}$.

In May 1860 Salvado requested a tillage lease of fifty acres from the government 'to encourage all the more to agricultural pursuits several aborigines of the mission'29.

Partly as a consequence of dwindling numbers of Aboriginal residents due to the devastating measles epidemic of 1861, Salvado began to recruit Aborigines from further afield. The mission began to house Aboriginal people from all over the south-west, not just the Yuit people and surrounding groups, but Aboriginal men and women from Bunbury and Albany in the south, Champion Bay to the north, and eventually, Roebourne and Wyndham in the far north. In 1870 Salvado also began accepting juvenile offenders who would have otherwise been sent to Rottnest Island Aboriginal prison ${ }^{30}$. Like other Aboriginal missions and stations around Australia, such as Coranderrk in Victoria and Poonindie in South Australia, Aboriginal people who came to New Norcia from other parts of the colony had already been dispossessed from their traditional lands and some had been institutionalised in other mission stations, surviving the transformations caused by pastoral invasion. Both New Norcia and Coranderrk became thriving and economically self-supporting communities. Similarities between New Norcia and Coranderrk are clearly evidenced in the early photographs of these two mission stations. As Anna Haebich has pointed out, photographs of these two stations are:

\footnotetext{
${ }^{28}$ E. J. Stormon: Memoirs, chapter 10.

29 'R. Salvado to Colonial Secretary, 18 April 1860', quoted in G. Russo (1977): Lord Abbot of the Wilderness: The Life and Times of Bishop Salvado, Melbourne: Polding Press, p. 154. The tillage lease was granted on $28^{\text {th }}$ May 1860.

${ }^{30}$ N. Green and L. Tilbrook (eds.) (1989): Aborigines of New Norcia, 1845-1914: The Bicentennial Dictionary of Western Australians, volume VII, Western Australia: University of Western Australia Press, p. xviii.
} 
dominated by tangible evidence of progress: cleared lands under crop, new buildings, Aboriginal children surrounded by the trappings of civilised life, sedentary families posed in the manner of colonial settlers outside their cottages, and scenes of community outings where residents relax on river side picnics or engage in the manly sport of cricket. Details of composition, the subjects' clothes, grooming and posture, and contextual props all combine to provide compelling proof of the missionaries' success ${ }^{31}$.

We might add to Haebich's statement that such photographs are also 'compelling proof of the Aborigines' success in adapting their land use. While acknowledging that such colonial photographs were for propagandist purposes and, no doubt, involved incidents of Aboriginal coercion, Haebich also argues that some photographs reveal 'intimations of Yuit people being in place in their country and of monks and transferred Aboriginal children coming to accept New Norcia as their home'32.

\section{AN ABORIGINAL TOWNSHIP}

New Norcia’s Aboriginal residents quickly became competent farmers. Father Garrido reported to Salvado in Rome in 1867 that 'Benedict Cuper and Albert Turgiel are ploughing and sowing their respective fields with two teams of oxen. They use an English plough, all their own property. They help each other alternately so that neither they nor the animals, whom they feed on hay, get tired. Tom Yawell and Bob Nogolot do the same'33. These men showed promising signs of missionary 'success' and the Brothers never missed an opportunity to report on their progress. One Brother, Romualdo Sala, wrote to his family in Spain, also in 1867, proudly describing how at New Norcia 'The shearers are Natives of the country who live in the Mission. They are very nimble. The "ringer" is called Benedict Cuper, and I've seen him shear 78 sheep

\footnotetext{
31 A. Haebich (2009): 'Unpacking Stories from the New Norcia Photographic Collection', New Norcia Studies, vol. 17, p. 57.

${ }^{32}$ A. Haebich (2009): 'Unpacking Stories...', p. 59.

33 'Letter from V. Garrido to R. Salvado, 21 April 1867', quoted in G. Russo, Lord Abbot of the Wilderness, p. 155.
} 
in a day. A. Thomas Yanel [Yawel] [has shorn] 61, William Manop [Monap] 55, Richard Caniel [Canhiel] 57, Donabuf [Donabut] 58 [...] $]^{34}$. Father Garrido also boasted about the shearers in his 1867 report: 'This very year, our natives have shorn 5413, that is, one of them (a half-caste) has sheared more than any European shearer employed here, namely 1421 sheep in twenty five days, paid at 4s 6d per score, £15 19s 8 1/2d’35. This was Benedict Cuper.

Benedict Cuper, born in 1846, was the son of an Englishman from Chittering in the Victoria Plains, and a Yuit woman named Maria Junnop. The historical record does not give us the details of exactly when and under what circumstances Cuper came to New Norcia, but by the time Salvado had returned from a trip to Europe in 1853, Cuper was listed as a resident. In 1857 there was a written agreement which stated that Cuper would stay at the mission until his $25^{\text {th }}$ year on an unspecified wage ${ }^{36}$. On 1 March 1861 he was on the books as a 'general servant', for which he was paid 20 shillings per month ${ }^{37}$. In 1865 Cuper made an agreement to wash and shear sheep, to be paid at a rate of 4 shillings and 6 pence per score and two bottles of colonial wine for every flock washed (minus his expenses and those of his men). This agreement Cuper signed himself on 9 September $1865^{38}$.

Cuper married Ellen Pangieran in 1862, and they were frequently used as pin-ups of New Norcia's success until Ellen's death in 1877. Ellen Pangieran, whose married name became Mary Ellen Cuper, was not a local Yuit woman, but had been born in Bunbury, to the south of Perth, in 1847. Because her mother had been deserted by Mary's European father, the government authorities considered that she was unable to bring up her daughter on her own. As a consequence, Mary was sent to New Norcia. While the patchy historical record tells a story of Benedict as a competent farmer, a star cricket player and a steady man, Mary Ellen is also renowned for being the first postmistress at New Norcia. Salvado taught Mary Ellen Morse Code in 1873 and she earnt a wage

\footnotetext{
${ }^{34}$ R. Sala: 'Letter Six', 16 October 1867, El Misionero Romualdo, translated and cited by David Barry (2005): 'A Mallorcan in New Norcia', p. 45.

35 'Letter from V. Garrido to Colonial Secretary', Information Respecting the Habits and Customs of the Aboriginal Inhabitants, p. 17.

${ }^{36}$ N. Green and L. Tilbrook (eds.) (1989): Aborigines of New Norcia, pp. 33-34.

${ }^{37}$ N. Green and L. Tilbrook (eds.) (1989): Aborigines of New Norcia, p. 34.

${ }^{38}$ N. Green and L. Tilbrook (eds.) (1989): Aborigines of New Norcia, p. 34.
} 
of $£ 30 \mathrm{p} / \mathrm{a}$ as postmistress. While Aboriginal men at New Norcia thrived in agricultural pursuits, some of the women found success in other employment.

Throughout the 1860s and 70s New Norcia received many visitors who published their observations in the local press. In April 1862, one visitor described the community. They visited the cottage where Benedict and Mary Ellen lived and were impressed that 'cleanliness and order seemed to reign everywhere'. Mary Ellen 'gave every positive promise of being a good and careful housewife' 39 . Visitors frequently requested to see the Aboriginal men cultivating the land, and Salvado showed them a field where they saw Benedict Cuper and Peter Nowarr and a 'Brother busily engaged in clearing, burning, and preparing the ground for the ploughing season'. This visitor was impressed with the work they saw, commenting also on how the profits of the previous year's crops enabled Cuper and Nowarr to purchase 'bullocks, drays, ploughs' and to 'comfortably maintain a wife!' ${ }^{20}$. The Aboriginal residents got used to performing for these observers, and were aware of the importance of appearances, particularly when Protestants came to scrutinise the Roman Catholics' civilising process. When Reverend Meadowcroft, a congregational minister, visited in 1873, Fr Santos Salvado sent a message notifying Mary Ellen two hours before he arrived, 'therefore', he wrote 'the sleeping room and the other rooms were swept, clean and the girls half-dressed-up and wearing shoes, waiting for Rev Meadowcroft in the living room' ${ }^{\prime}$.

Another New Norcia resident, named Charles (Carlos) Ponan - the stepbrother of Benedict Cuper's wife, Mary Ellen (they shared the same European father), and whose ancestral country was near Bunbury - frequently worked with Cuper as a team, hunting and breaking in horses (caballeros), sinking wells, repairing fences and harvesting New Norcia landholdings, as well as operating their own farms ${ }^{42}$. Ponan arrived at New Norcia in 1862 . He was baptised that year with Cuper as his godfather. In 1869 he married Mary Lucy

\footnotetext{
39 Perth Gazette, 11 April 1862, p. 4.

${ }^{40}$ Perth Gazette, 11 April 1862, p. 4.

41 'Letter from S. Salvado (New Norcia) to R. Salvado (Perth), 15 February 1873', in Spanish and English, NNA 2-2234A/28.23, translated from the Spanish by Teresa de Castro.

${ }^{42}$ Examples litter the correspondence between Fr Santos Salvado and Rosendo Salvado in 1876-79; Salvado, List of "caballeros", 31 December 1876, ACC 2-2234A/file 31.163, translated from Spanish by Teresa de Castro.
} 
Bouyacan and they had seven children ${ }^{43}$. Under the Land Regulations of 1872 Crown land could be set aside for use by Aborigines, as a gazetted reserve. Small reserves were created as sites for mission schools. New Norcia received 29 acres in 1874 and Cuper and Ponan received land under this scheme ${ }^{44}$. However, Benedict also had a large field which he cleared and cultivated prior to this. In September 1869 , as the mission community was expanding, Salvado decided to divide Benedict's field into three portions: 'the part from the road towards the river, which has the best soil, for Benedict; the part that goes to the mission, for Ponan; and the area that goes to the road towards the river and between the 2 fences, for Manop [Monap]'45.

In 1876, Salvado wrote in his Diary that Cuper and Ponan 'own their own farms of 100 acres each around New Norcia, and farm them under the supervision of a Brother. Last season I paid them $£ 50$ each for their harvest ${ }^{\not 46}$. Historian George Russo has described how, for the benefit of these farmers, Salvado established a 'rural bank to provide credit for their farms. They could buy sheep and cattle, which meant that they could become pastoralists in their own right, and with the experience gained at the mission they could settle themselves anywhere in Western Australia' ${ }^{27}$.

By the 1880s New Norcia had achieved pastoral dominion in the Victoria Plains district, including several mission outposts, causing some settlers to state that Salvado had 'picked the eyes out of the country'48. In 1885, 967,000 acres were held by New Norcia. One reason given for holding such a big area was the need for funds, to maintain their very large establishment of Aboriginal dependents at the mission. Another was the original aim of settling Aboriginal families on different blocks of land to be parcelled out to them for their exclusive use ${ }^{49}$.

\footnotetext{
${ }^{43}$ N. Green and L. Tilbrook (eds.) (1989): Aborigines of New Norcia, p. 119.

${ }^{44}$ L. Tilbrook (1983): Nyungar Tradition: Glimpses of Aborigines of South-West Australia, 1829-1914, Western Australia: University of Western Australia Press, pp. 28-29.

45 'Letter from R. Salvado (Rome) to V. Garrido (New Norcia), 21 September 1869', NNA, 2-2234A 124.190, Spanish and Latin.

46 Salvado: Diary, 29 ${ }^{\text {th }}$ March 1876, quoted in G. Russo, Lord Abbot of the Wilderness, p. 212.

47 G. Russo: Lord Abbot of the Wilderness, p. 212.

${ }^{48}$ R. Erickson (1971): The Victoria Plains, Osborne Park, Western Australia: Lamb Patterson, p. 49.

${ }^{49}$ R. Erickson (1971): The Victoria Plains, p. 54.
} 
With a post and telegraph office run by Aboriginal residents (Sarah Minak took over as postmistress when Mary Ellen died), a court house, a police office, a successful Aboriginal cricket team and an Aboriginal choir, New Norcia reflected Salvado's vision of a steady, stable Aboriginal village. In the $1880 \mathrm{~s} \mathrm{New}$ Norcia appeared to be flourishing. Governor Broome's wife, Lady Broome, wrote about the outcome of Salvado's vision after spending a night at New Norcia in 1883: 'One saw the result of it all during the long, pleasant day spent in visiting schools and workshops, going into the neat, comfortable cottages, and finally sitting down to watch a capital game of cricket between the natives and the lay Brothers' ${ }^{50}$. In 1884, Brother Romualdo Sala called New Norcia a 'town of Indigenous Aborigines', and he described the four streets of Aboriginal cottages, listing the names of the male heads of the families who occupied each of the 21 cottages $^{51}$.

While agriculture was the main priority at New Norcia, reading, writing and religious instruction were also central to mission life. The Brothers encouraged letter writing and also urged Aboriginal residents to join petitions that the community was involved in.

In September 1864, 'the first natives', who had been sent from Bunbury to New Norcia by Fr Lecaille, wrote him a letter 'thanking him for his great charity towards them'52. On Salvado's $62^{\text {nd }}$ birthday in 1876, he was in Europe, where he received three telegrams from New Norcia wishing him a happy birthday: 'one from the community, one from the natives and the third one from Benedict Cuper and his wife'53. Letters were sometimes written between New Norcia and the Aborigines who were living and working on the mission's outstations. James Cooper Nindimara, who was based on an outstation at Jibberding, wrote to Salvado in 1889 describing the 'troublesome' Aborigines who visited Jibberding, hoping for 'silavtion [salvation] for the poor sogles [souls] ${ }^{54}$. This letter reveals

\footnotetext{
${ }^{50}$ A. Hasluck (ed) (1963): Remembered with affection: A New Edition of Lady Broome's 'Letters to Guy', with notes and a short life, Letter IX, Melbourne: Oxford University Press, p. 72.

${ }^{51}$ R. Sala: Letter 18, 2 May 1884, El Misionero Romualdo, translated and cited by David Barry (2005): 'A Mallorcan in New Norcia', pp. 48-49.

52 The letter is mentioned in 'Letter from Salvado to Lecaille, 22 September 1864', NNA ACC 205, 2-2234A/19.205.

53 Salvado: Diaries, vol. 2, 1 March 1876, translated from the Spanish by Gustavo Geuna. NNA.

54 'Letter from James Cooper Nindimara to Salvado, 22 August 1889', NNA ACC 2-2234A/44.91.
} 
a division between the Christian/non-Christian Aboriginal population, and the labouring/non-labouring population.

Several Aboriginal people at New Norcia were signatories to a petition in 1865 that Father Garrido organised, requesting that Salvado remain the principal of New Norcia, rather than relocating to Subiaco ${ }^{55}$. It is hard to know if these Aboriginal petitioners signed the petition because Salvado was viewed as the leader integral to their land acquisition.

\section{0: STRUCTURAL CHANGES}

After 1890 many factors contributed to a change in the lifestyles of New Norcia's Aborigines. Following a sustained campaign led by the editor of The West Australian, Winthrop Hackett, to eliminate government support for Church schools and institutions, New Norcia now held total financial responsibility for the adult population at the mission. This reduced funding forced many families to leave New Norcia for outside employment ${ }^{56}$. Salvado expressed his disappointment about this in a statement to the Aborigines Protection Board in 1893: 'It may be as well to add the following natives [six names of Aborigines and half-castes] left this mission with their wives and children this year, intending to earn better weekly wages somewhere else, as one guinea per week to each married native is as much as the mission can afford to pay them'57. In February 1899 Cuper - who had married Matilda Murrichery in 1893 after the death of Mary Ellen - had moved to Wyening, an outpost of the mission. He agreed to make a tank at a rate of 1 shilling and 1 penny per cubic yard. All tools were to be supplied by $\mathrm{Cuper}^{58}$.

\footnotetext{
55 'Letter from V. Garrido (New Norcia) to Salvado (Rome), 8 March 1865', NNA ACC 57, 2-2234A 120.057.

${ }^{56}$ N. Green and L. Tilbrook (eds.) (1989): Aborigines of New Norcia, pp. xviii-xix.

57 'Statement Concerning the Natives (Aborigines and Half-castes) at the Benedictine Mission of New Norcia, on the 31 $1^{\text {st }}$ December 1893', Correspondence Relating to the Proposed Abolition of the Aborigines Protection Board of Western Australia, British Parliamentary Papers, C. 8350, Document F, State Records Office of Western Australia.

${ }^{58}$ N. Green and L. Tilbrook (eds.) (1989): Aborigines of New Norcia, p. 34 . In 1898 Cuper, aged 50 years, was listed as living with Matilda and her children Lucas, Rosendo and Rose Murrichery in house 4, row 1 at New Norcia, before moving to Wyening the following year.
} 
The change of mission superintendent in 1900 following Salvado's death saw mission life become highly regulated under missionary control, and many residents were forced off the mission. Salvado's successor, Abbot Fulgentius Torres, has been identified by historians as the instigator of many changes at New Norcia, in particular with the turn away from a mission for Aboriginal people and towards the education of Catholic settler children, with the change of focus to a cloistered monastery. Katharine Massam has argued that these changes were not so much due to a reluctance to continue missionary endeavour but rather a desire to focus more firmly on monasticism ${ }^{59}$. The missionary effort moved to the Drysdale River Mission, which opened in Napier Broome Bay, on the Kimberley coast, in 1908. Torres drastically reduced New Norcia's large land holdings to just 41,000 hectares by $1909^{60}$. This in turn reduced the need for shepherds and the mechanisation of Australian agriculture further reduced the labour needs of New Norcia. In the 1880s there had been 21 Aboriginal cottages. These were demolished as New Norcia underwent major changes.

Bishop Torres 'encouraged monks and brothers at New Norcia to abandon their outdoor rural work and to lead a more refined and secluded life ${ }^{61}$. Peggy Brock has narrated a similar story at Poonindie: 'By the late 1860s the initial idealism of Hale [Poonindie's founder] and his graduates had dissipated [...] and had been replaced by an institutional ethos of supervision and control' ${ }^{62}$. Similarly, the Kulin residents at Coranderrk experienced a dramatically different structure to their daily life when the popular station manager at Coranderrk, John Green, was forced to leave.

In 1911, one Aboriginal resident at New Norcia, George Shaw, who was very vocal against the changes to mission life, wrote to the Aborigines Department, stating that the mission was 'no home for the native at all. They keep a few hands here to carry bricks because they are cheap but I can assure you that if you are sick they have no time for such a native' 63 .

\footnotetext{
${ }^{59}$ K. Massam (2012): 'Cloistering the Mission: Abbot Torres and Changes at New Norcia 1900-1910', Australasian Catholic Record, 89 (1), p. 14.

${ }^{60}$ N. Green and L.Tilbrook (eds.) (1989): Aborigines of New Norcia, p. xix.

${ }^{61}$ A. Haebich: For Their Own Good, pp. 16-17.

${ }^{62}$ P. Brock (2000): 'Mission Encounters in the Colonial World: British Columbia and South-West Australia, Journal of Religious History, vol. 24, 2, June, pp. 170-171.

63 'Letter from George Shaw to Aborigines Department', AF 473/1911, quoted in A. Haebich, For Their Own Good, p. 19.
} 
Despite, or perhaps because of these changes at New Norcia, in the early 1900s several Aboriginal farmers were granted land by the Crown. The government Land Regulations can also be understood as undoing part of the mission's previous success. While granting Aborigines land, the rigid requirements also created failures out of this scheme. As Haebich has argued, 'The conditions under which these blocks were granted created insurmountable financial difficulties for Aboriginal farmers and it was the system of land tenure and the conditions of occupancy [...] which proved the major barrier to Aborigines succeeding on the land'64.

\section{LAND REGULATIONS - ABORIGINAL FARMS}

As Commissioner for Crown Lands John Forrest ushered through a new set of land regulations through the Legislative Council, directed at finding a middle

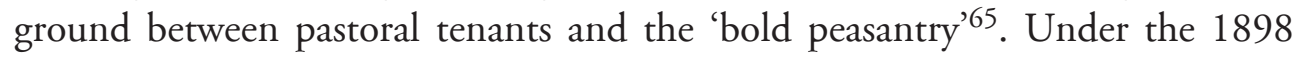
Land Act, up to 200 acres of land could be granted or leased to an Aboriginal on application, for the purpose of residence or cultivation. If certain improvements were not made within a specified period the occupant stood to lose the land, which could then be re-classified as Crown land. To ensure that the land was fully utilised, its transfer was made conditional on the holder carrying out certain improvements within a specified period ${ }^{66}$. The Lands Department followed the recommendation of the Commissioner for Crown Lands in 1895 that reserve holders be required to carry out improvements to their blocks or face having them reduced in size or cancelled. Reserve holders were subject to the terms of occupancy for homestead blocks; within two years of taking up land they were required to erect a dwelling valued at $£ 130$ or have an equivalent area under crop; within five years they were to fence in a quarter of their block and within seven years the entire block was to be fenced.

Several Aboriginal people obtained land under these provisions. In 1906 twelve Aborigines applied to the Lands Department for farming blocks. As

\footnotetext{
${ }^{64}$ A. Haebich: For Their Own Good, p. 30.

${ }^{65}$ R. Erickson: The Victoria Plains, p. 65.

${ }^{66}$ A. Haebich: For Their Own Good, p. 11.
} 
Haebich has written, 'most applied on their own initiative, while others were encouraged in their endeavours by missionaries, employers or well-meaning government officers. Most applicants were mature, married men with young families and considerable experience on the land'67. A large number of these applicants were men who had been educated at New Norcia who had some association with the land through ancestral connections or long-term residence in the areas in which the blocks were located.

The special provision for grants of land to Aborigines was first introduced in the 1887 Land Regulations. However, as Haebich has argued, in introducing this provision the government appears to have had no clear-cut policy on the role of Aborigines in land development. It certainly had no intention of granting Aborigines full ownership of these blocks. Forrest told the Legislative Council in 1886 that the clause was intended merely to allow the Governor to 'give away the land' and the Acting Attorney General, S. Burt, added in support of Forrest that 'a native could hardly be allowed to come under the transfer clause' ${ }^{68}$. The government most likely predicted that the clause would enable the development of Aboriginal farming settlements supported by missionary agents in a similar context to New Norcia. The government would have had some awareness of the 'success of the Aboriginal farming settlements, Coranderrk and Cumeroogunga' 69 .

The Lands Department and Chief Protector of Aborigines correspondence files contain examples of a pessimistic attitude to Aboriginal farming that was present in the community at this time. For example, A. R. Richardson, Commissioner of Crown Lands, wrote to the Under Secretary for Lands in 1896 when he had made the decision to cancel the reserve of an Aboriginal farmer in Katanning. 'I consider it quite useless and never likely to succeed', he wrote, 'this idea of natives or even half-castes settling or cultivating the Reserves - "it is not in them" 70 . There was an expectation that Aborigines would fail to make sufficient improvements, continuing a long-held belief that Aboriginal people

\footnotetext{
${ }^{67}$ A. Haebich: For Their Own Good, p. 28.

${ }^{68}$ Quoted in A. Haebich, For Their Own Good, pp. 28-29; for the debate see Western Australian Parliamentary Debates 11, 1886: 246, State Records Office of Western Australia.

${ }^{69}$ A. Haebich: For Their Own Good, p. 29.

70 'A. R. Richardson to Under Secretary for Lands, 26 October 1896', 1896/5926, SRO WA. Alex Richardson was a Pilbara squatter who would have had little experience of New Norcia. He probably formed his opinions about Aboriginal incapacity during his experiences of the remote Pilbara frontier.
} 
were not capable of settling and cultivating the land. When Paul Piramino, from New Norcia, applied to the Aborigines Department in 1905 to obtain a saw to use when working on his land, the Protector sent an inspector to report on the improvements Piramino had made, and afterwards concluded: 'It is as I thought - Piramino will never do much work either on his own land or anyone else's. Do not send the saw ${ }^{71}$.

Luke Mourdey, Benedict Cuper, Charles Ponan, Paul Narrier and Paul Piramino were some of the Aboriginal individuals who had land at or near New Norcia as part of these land regulations. However, lack of capital, together with the need to support their family, meant that these men had to find work to supplement their income and sometimes struggled to keep up the improvements on their farms. When their leases were cancelled they were faced with a second wave of dispossession, but they fought, sometimes successfully, to retain access to and ownership of their land. Having been removed from their traditional country decades earlier and relocated to a new country, these stories of Aboriginal farmers facing a re-dispossession are similar to the struggles for land that took place at Coranderrk Aboriginal Station. Both New Norcia and Coranderrk reveal rare examples of bureaucratic decisions against Aboriginal people being revoked due to Aboriginal and humanitarian protest.

The protests by New Norcia residents were conducted in a mode that they had developed alongside the Benedictine Brothers and which reveal the Aborigines' strong convictions of kuoba and winda, right and wrong. Richard Broome has argued persuasively that at Coranderrk the Aboriginal residents acted on their belief of what he has termed right behaviour. 'Their relationship to the natural world was governed by rich protocols and taboos and social relations were highly ritualised $[\ldots]^{772}$. Aboriginal people had laws and customary understandings about correct conduct, expressed particularly in the idioms of kinship and reciprocity'. The Kulin, Broome argues, acted on these beliefs, particularly 'with regard to issues of management and rationing'73.

\footnotetext{
${ }^{71}$ Chief Protector of Aborigines, 21 January 1905, Cons 652, SRO WA.

72 R. Broome (2006): “There were vegetables every year Mr Green was here”: Right behaviour and the struggle for autonomy at Coranderrk Aboriginal Reserve', History Australia, vol. 3, no. 2, p. 43.1.

${ }^{73}$ R. Broome (2006): “"There were vegetables every year Mr Green was here”, p. 43.2.
} 
Aboriginal people's rights and entitlements at New Norcia were expressed in writing as early as 1861 when a group of 18 Aboriginal residents signed a petition complaining that one of the Brothers at the mission had shot one of their dogs. This group knew what they were legally entitled to: 'the Government allow us natives onley one Dog to each natives'. They reported the story of their dog being shot by one of the Brothers: 'now last night your, Revs some of the Brothers shoot one of the natives Dogs through the Hart and we all things that is not good enough for us all'. This group stated their idea of what would be considered fair and just:

[...] we all natives whould have nothing to say to you you, Rev. F Betteran if the Brother that shoot the Dog at time when the Dog pat the sheep doun on the ground and trying to kill the sheep it is his Plaice to shoot the Dog because the Dog trye to kill the sheep [...] we all natives things that is a rong thing to too us poor natives some of us have got large famley and I say again that to have one Dog each marrage men withe large famley it is a good healp to us at sundays to go out to get Kangeroo or some other things in the Bush. we say again the Brother that shoot the Dog last night your, Revn.s we all thing he tone a bat thing thire was no sheep in the field and the Dog whent to have a swim and the River Brother shoot it and kill it.

The letter ended with the statement: 'We all natives hav Nomore to say tou your Revens and we all remain your Faithfull Servends' 74 . The first signature was Paul Piramino. Mary Ellen Cuper was also one of the signatories.

Other written protests concerned rations and blankets. Felix Jackimara and George Shaw, for example, both believed they were entitled to more than they were receiving, and in 1911 wrote to the Chief Protector asking for more flour and rugs ${ }^{75}$. These were important moral statements for right treatment.

In May 1907 three reserves which had been set aside for use by Aborigines were cancelled and opened for public selection, as it was thought that insufficient improvements could be shown on them. One of these blocks belonged to Charles Ponan at Catabody in Wyening. Haebich has suggested that adjoining

\footnotetext{
74 'Letter from several Aborigines to Rev Bertran', undated, 1861, NNA ACC 2224A/16.163.

75 'Letter from George Shaw to Mr Gale, 27 April 1911', Cons 652 1911/473, SRO WA; 'Letter from Felix Jackimara to Mr Gale, 27 April 1911', Cons 652, 1911/473, SRO WA.
} 
white farmers reported Ponan's lack of cultivation to the Lands Department in order to 'gain possession' of Ponan's land themselves ${ }^{76}$. Ponan protested to the acting Chief Protector of Aborigines, E. Pechelle, with the help of a neighbour who transcribed a letter for him. He argued that if he was moved off his land the government ought to pay him compensation for the improvements he had made to his country: 'I think it is not a fair thing to have me shifted out of my best ground and what labour I done in it. I hope you will see into this for me [...]. I am in my ground, I will not shift from what labour I have done in it until I hear from your reply ${ }^{37}$. Ponan described how he had 'ringed 20 acres and cleared 10 acres and got a little $1 / 2$ acre garden, sunk a tank three feet deep and two yards wide' ${ }^{78}$. His letter persuaded the Protector, and in November 1907 his block of land was again classified as a reserve for use by an Aboriginal, and he remained there. Ponan had the determination to object to the Protector about his land being taken away, and stressed his desire to retain it, fighting for what he considered to be rightfully his.

The idea of payment for the labour Ponan had done on his country had its seeds in the structure of labour and wages that Salvado set up at New Norcia, where 'to have Aboriginal men working without recompense or reward would make them feel the burden of civilisation without its advantages [...] Properly instructed the aboriginal acquires a just idea of both the value of money and property, and diligently studies thenceforth how we may better his condition'79.

Some Aborigines, such as Luke Mourdey and Benedict Cuper, applied to the Aborigines Department for assistance with farming equipment (tools, fencing wire, and corrugated iron) in developing their farms. Both received some capital assistance after a period of protracted negotiations, during which time Mourdey was nearly impoverished. Often these negotiations with the Aborigines Department were made with the help of neighbouring settlers or missionaries at New Norcia.

\footnotetext{
${ }^{76}$ A. Haebich: For Their Own Good, p. 32.

77 'Letter to E Pechell, acting Chief Protector of Aborigines, from Charles Ponan, Catabody, Monday 26 [August] 1907', ADF 1907, 357, SRO WA.

78 'Letter to E Pechell, from Charles Ponan, Monday 26 [August] 1907'.

${ }^{79}$ E. J. Stormon: The Salvado Memoirs, chapter 10.
} 
Cuper had a block at Wyening and by 1905 had fifteen acres under crop, fifty cleared and ready for ploughing and posts ready for one hundred chains of fencing. On 29 th November 1905, Cuper's local Member of Parliament, G. W. Gardiner, wrote a letter to Henry Prinsep, Chief Protector of Aborigines. Gardiner described Cuper's productivity: 'I noticed he has a good deal of improvement done - there are a good deal of posts in the ground ready for the wire - I know him to be a steady hard working man and he ought to be encouraged' ${ }^{20}$. Henry Prinsep wrote to E. Pechelle on $1^{\text {st }}$ December 1905, stating that he had spoken to Gardiner and received a letter from H. W. Phillips, a neighbour of Cuper's, also supporting Cuper, and that Cuper was 'well worthy of encouragement as he was a well conducted industrious man living on a block of land obtained from the Lands Department under their Regulations as an aboriginal'. Prinsep added that 'the man himself subsequently came to see $m e^{31}$. In his presentation to the authorities for assistance, Cuper not only wrote letters himself, he gathered a small network of powerful figures to speak on his behalf: New Norcia mission authorities, a white neighbour and his local Member of Parliament. With the help of this network, combined with Cuper's success on the land and his reputation as a steady and industrious man, he was a challenge to the expectation that some settlers had of indigenous capabilities and achievement.

The department agreed to supply his wire. On 30 December 1905 Cuper wrote to Prinsep thanking him for the wire. In this letter Cuper also reveals that he, perhaps, knew Prinsep well: he asked after Rose and Charles 'wishing them luck at school' and reminds Prinsep 'you promas me that poto' of his family ${ }^{82}$. However, Cuper was not always successful in his applications to government. In 1914 his application for the old-age pension was rejected because he came under the 1905 Aborigines Act. This created financial difficulty and he lost his land soon after ${ }^{83}$.

Luke Mourdey was granted land in 1903 but it was also cancelled and then returned to him following his written objections to the authorities ${ }^{84}$. It is worth

\footnotetext{
80 'Letter from G. W. Gardiner to H. Prinsep, 29 November 1905', Cons 255, 1907/726 SRO WA.

81 'Letter from Prinsep to E. Pechelle, 1 December 1905', Cons 255, 1907/726 SRO WA.

82 'Letter from Benedict Cuper to Henry Prinsep', Cons 255, 1907/726 SRO WA.

${ }^{83}$ A. Haebich: For Their Own Good, p. 32.

${ }^{84}$ A. Haebich: For Their Own Good, p. 384.
} 
considering the ways in which Aboriginal farmers portrayed themselves in their letters to authority. Both Mourdey and Cuper changed their surnames when writing to authorities. 'Luke Mourdey' was almost certainly an alias for Lucas Murrichery, Benedict Cuper's stepson. In all of Cuper's correspondence and contracts about his land he signed as 'Cooper'. Lucas Murrichery adopted the more English name of Luke Mourdy (also written as Moody). It is difficult to know why Cuper and Murrichery did this. It could be understood as a strategic attempt to appear less 'Aboriginal' to the authorities, emphasising their farming identity over their Aboriginal one as a way of affecting change. Interestingly, in correspondence in May 1898 between Fr Dominguez and Salvado, Salvado expressed concern about Cuper's use of 'Cooper' when he signed a legal document. Salvado 'got upset at seeing that Cuper has signed as "Cooper" (an English surname) because the Document and his marriage certificate are under "Cuper" (his Australian name), a fact that could invalidate the document' 85 . Salvado urged Dominguez to make "Cuper sign several times as Cuper so that [...] he won't make the same mistake' ${ }^{86}$. Salvado was clear about his encouragement of the 'Australians' to take a baptismal name as well as keeping their indigenous surname when they came to New Norcia.

While the Aboriginal 'rebellion' at Coranderrk has been well documented by historians, the instances of political traction at New Norcia, while less publicly voiced than those of Coranderrk, also reveal Aboriginal individuals identifying and claiming the rights that they believed they were entitled to. The narrative of Salvado's missionary 'success' and his enlightened approach to 'civilising' the Aboriginal people who came to New Norcia has overshadowed the story of the political agitations of some of the mission residents in the early 1900s. As this chapter has discussed, Aboriginal people's expectations, ideas of entitlement and land rights can be tracked through the New Norcia archives, in their petitions, letters and actions, and in the way they identified themselves ${ }^{87}$.

\footnotetext{
85 'Letter from Salvado (Perth) to Dominguez (New Norcia), 19 May 1898', NNA ACC 2-2234A/53.97. 86 'Letter from Salvado (Perth) to Dominguez (New Norcia), 19 May 1898', NNA ACC 2-2234A/53.99.

${ }^{87}$ The changes brought about by Torres and his successor, Dom Catalán (1916-1951), focused on monastic life and increased engagements with the local settler community. New Norcia's Aboriginal schools closed in 1971 and formal secondary education ceased with the closure of New Norcia's Catholic college in 1991. Today the town operates as a site for spiritual retreats, a tourist attraction and the Education Centre offers school programs including Aboriginal studies. In 2008 a restoration project began and the last remaining Aboriginal cottage - which had been used as a public toilet since the 1950 s - was restored.
} 